\title{
POTENSI EKSTRAK DAUN KOKANG (Lepisanthes amoena (Haask) Leenh) SEBAGAI OBAT LUKA
}

\author{
Henny Hidayah, Rolan Rusli, Herman, Muhammad Amir Masruhim \\ Laboratorium Penelitian dan Pengembangan FARMAKA TROPIS Fakultas Farmasi \\ Universitas Mulawarman, Samarinda, Kalimantan Timur \\ email: rolan@farmasi.unmul.ac.id
}

\begin{abstract}
ABSTRAK
Daun kokang (Lepisanthes amoena (Haask) Leenh) secara empiris digunakan sebagai pembersih tubuh dan wajah, memiliki kandungan metabolit sekunder yang berpotensi sebagai antimikroba. Penelitian ini bertujuan untuk mengetahui potensi ekstrak daun kokang dalam penyembuhan luka. Metode yang digunakan adalah metode Morton yang dimodifikasi dengan menggunakan konsentrasi ekstrak sebesar 2,5\%; 5\%, 7,5\%, dan $10 \%$, serta bioplasenton sebagai kontrol positif dan aquadest sebagai kontrol negatif. Data hasil penelitian dianalisis menggunakan anava satu arah dilanjutkan dengan uji BNJD. Hasil penelitian menunjukkan bahwa ekstrak daun kokang dapat berpotensi sebagai obat luka dengan konsentrasi 5\%, 7,5\%, dan 10\% dengan lama penyembuhan luka sekitar 1316 hari.
\end{abstract}

Kata Kunci: Ekstrak daun Kokang (Lepisanthes amoena (Haask) Leenh), obat luka, lama penyembuhan luka

\section{PENDAHULUAN}

Daun kokang (Lepisanthes amoena (Haask) Leenh) secara empiris digunakan sebagai pembersih tubuh dan wajah oleh masyarakat suku dayak dan kutai sebagai pengganti fungsi sabun mandi karena daun kokang mengeluarkan busa seperti sabun.

Daun kokang memiliki kandungan metabolit sekunder, seperti senyawa fenolik, flavanoid, tanin, steroid, dan saponin (Rijai, 2008).

Lebih lanjut Eka (2011) melaporkan bahwa ekstrak fraksi $n$ butanol daun kokang berpotensi sebagai antimikroba terhadap beberapa jenis bakteri patogen seperti Pseudomonas aeruginosa, Salmonela thyposa, dan Staphilococus aureus.

Akan tetapi belum ada peneliti yang melaporkan potensi ekstrak daun kokang sebagai obat luka. Oleh karena itu, artikel ini dilaporkan mengenai potensi daun kokang sebagai obat luka karena dalam daun kokang terdapat beberapa metabolit sekunder yang dapat berfungsi sebagai antioksidan dan antimikroba.

\section{METODE PENELITIAN}

\section{Bahan}

Daun kokang, tikus putih jantan (Ratus norvegiens), etanol, bioplasenton, dan aquadest.

\section{Peralatan}

Alat potong, toples kaca, rotary evaporator, desikator, timbangan analitik, kandang hewan coba, alat cukur, pisau bedah, penggaris, botol tetes coklat, batang pengaduk, kertas saring, gunting, pipet tetes, labu ukur, dan spoit. 


\section{Prosedur}

Daun kokang diektraksi dengan etanol, kemudian ekstrak yang dihasilkan dipekatkan dengan menggunakan rotary evaporator, dan ekstrak pekat dikeringkan dalam deksikator. Ekstrak yang dihasilkan dibuat dalam seri konsentrasi yaitu konsentrasi 2,5\%; 5\%, 7,5\%, dan $10 \%$. Ekstrak diujikan pada tikus putih yang telah dilukai bagian punggungnya mengikuti metode Morton yang dimodifikasi. Lamanya penyembuhan luka dengan penggunaan Ekstrak dibandingkan dengan penggunaan bioplasenton sebagai kontrol positif dan aquadest sebagai kontrol negatif. Data hasil penyembuhan luka pada tikus putih tersebut dianalisis dengan menggunakan analisis statistik Anava satu arah dan dilanjutkan dengan uji BNJD.

\section{HASIL DAN PEMBAHASAN}

Aktivitas ekstrak daun kokang dalam menyembuhkan luka, dapat dilihat dari semakin mengecilnya ukuran luka atau semakin besarnya diameter ukuran penyembuhan luka pada tikus putih. Data aktivitas lama penyembuhan luka dan ukuran penyembuhan luka dapat dilihat pada Gambar 1.

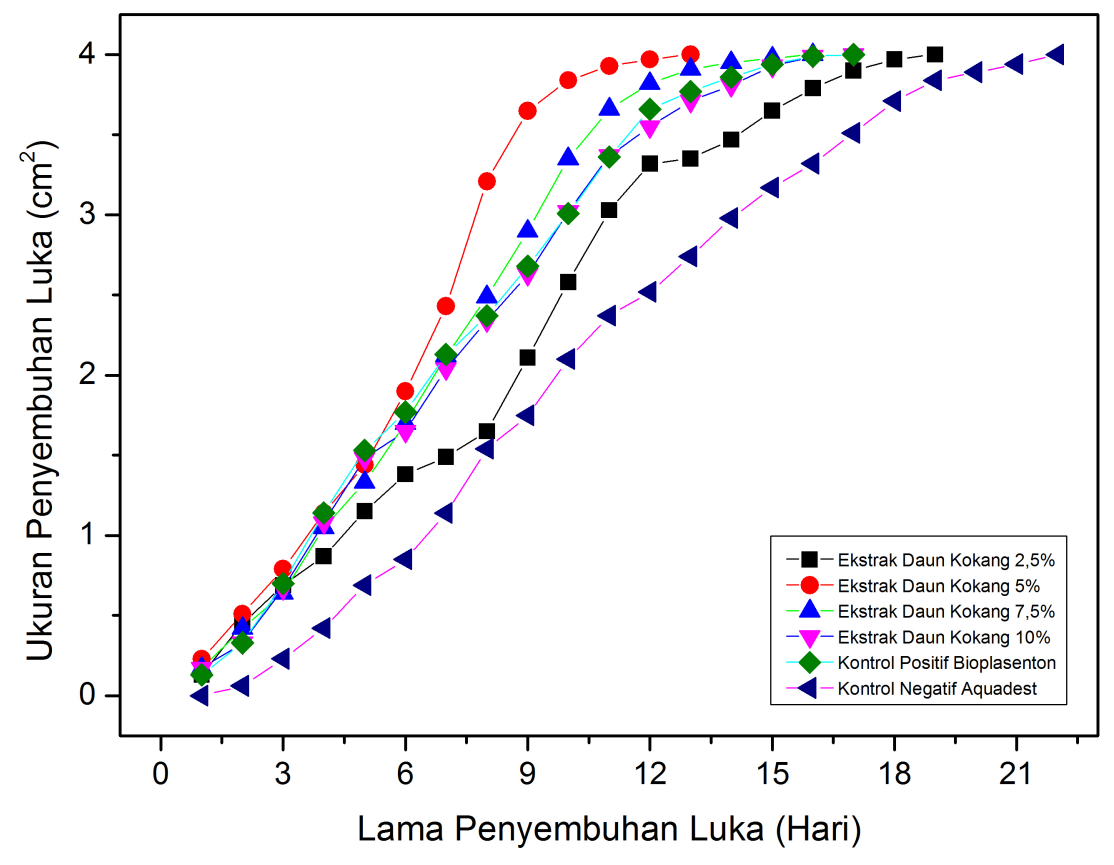

Gambar 1. Lama penyembuhan luka dan ukuran penyembuhan luka ekstrak daun kokang (Lepisanthes amoena (Haask) Leenh)

Berdasarkan gambar 1, dapat dilihat bahwa lamanya penyembuhan luka menggunakan ekstrak daun kokang dengan konsentrasi 2,5\%, 5\%, 7,5\%, dan $10 \%$, adalah berturut-turut sekitar 17 hari, 13 hari, 15 hari, dan 16 hari. Sedangkan lama penyembuhan luka dengan menggunakan bioplasenton dan aquadest adalah sekitar 17 hari dan 22 hari. Dengan demikian dapat dikatakan bahwa ekstrak daun kokang dapat menyembuhkan luka pada semua konsentrasi uji yang dilakukan. Selain itu ekstrak daun kokang lebih cepat dalam menyembuhkan luka dibandingkan dengan penggunaan bioplasenton dan aquadest. 
Efektifitas ekstrak daun kokang dalam penyembuhan luka ini diduga karena dalam ekstrak daun kokang memiliki senyawa-senyawa metabolit sekunder yang berfungsi sebagai antioksidan dan antibakteri seperti yang telah dilaporkan oleh Eka (2011). Beberapa senyawa antimikroba yang berperan dalam penyembuhan luka yang terdapat dalam ekstrak daun kokang seperti senyawa senyawa fenolik, flavanoid, tanin, steroid, dan saponin seperti yang telah dilaporkan oleh Rijai (2008).

Berdasarkan hasil uji statistik anava satu arah yang dilanjutkan dengan uji BNJD yang dilakukan pada ekstrak daun kokang dibandingkan dengan kontrol positif biplasenton diperoleh bahwa ekstrak daun kokang dengan konsentrasi 5\%, 7,5\%, dan $10 \%$ memiliki pontensi sebagai obat luka.

\section{KESIMPULAN}

Ekstrak daun kokang dapat berpotensi sebagai obat luka dengan konsentrasi $5 \%, 7,5 \%$, dan $10 \%$ dengan lama penyembuhan luka sekitar 13-16 hari.

\section{DAFTAR PUSTAKA}

1. Eka, S., 2011. Potensi Ekstrak Fraksi n-butanol Daun Kokang sebagai Antibakteri. Skripsi. Fakultas Farmasi Universitas Mulawarman Samarinda.

2. Nugroho, Agung Endro. 2006. Hewan Percobaan Diabetes Millitus: Patologi dan Mekanisme Aksi Diabetogenik.UNS: Surakarta

3. Katzung., Bertram G. 2000, Farmakologi Dasar dan Klinik, Penerbit ECG. Jakarta.

4. Rijai, L., 2008. Penelusuran dan Bioaktivitas Tumbuhan Obat di Kabupaten Kutai Barat. Fakultas Farmasi Universitas Mulawarman Samarinda. 